\title{
Characteristics of Phosphorus Loss from the Weathered Granite Slopes of Southeast China
}

\author{
Longzhou Deng ${ }^{1}$, Kai Fei ${ }^{1}$, Tianyu Sun ${ }^{1}$, Liping Zhang ${ }^{1 *}$ \\ Xiaojuan Fan', Yanhong $\mathrm{Wu}^{1}$, Liang $\mathrm{Ni}^{2}$ \\ ${ }^{1}$ College of Environmental and Resource Sciences, Zhejiang University; Zhejiang Provincial Key Laboratory \\ of Agricultural Resources and Environment, Hangzhou, China \\ ${ }^{2}$ Agricultural Experiment Station, Zhejiang University, Hangzhou, China
}

Received: 25 April 2019

Accepted: 23 July 2019

\begin{abstract}
The method of artificial rainfall simulation was applied to study the effects of different slope gradients $\left(8^{\circ}, 15^{\circ}\right)$ and rainfall intensities $(1.0,1.5,2.0,2.5 \mathrm{~mm} / \mathrm{min})$ on the pathways of phosphorus (P) loss from the weathered granite slopes of southeast China. The results showed that the runoff yield increased with runoff time while the sediment yield first increased and then decreased. The subsurface flow showed a changing trend of single-peak curve with maximums appearing under the rainfall intensity of $1.5 \mathrm{~mm} / \mathrm{min}$. The $P$ loss amount increased with increasing rainfall intensity and slope gradient and was mainly carried away by eroded sediment that accounted for $54.23-95.62 \%$. The mass concentrations of TP, DP and PP in runoff decreased with runoff time. The P lost via runoff from the sloping land was mainly in the form of DP, most of which reached more than $50 \%$. Surface flow was the dominant pathway of $\mathrm{P}$ loss via runoff and it presented a positive power correlation with rainfall intensity $\left(\mathrm{R}^{2}>0.982\right)$. It was necessary to attach great importance to $\mathrm{P}$ loss via subsurface flow, though the total loss amount was small compared to that via surface flow and sediment.
\end{abstract}

Keywords: phosphorus loss, slope gradient, rainfall intensity, artificial simulated rainfall, weathered granite slope

\section{Introduction}

The excessive discharge of phosphorus $(\mathrm{P})$ is one of the critical reasons for eutrophication that greatly influences water quality and aquatic ecosystems [1, $2]$. The major cause of increasing $P$ concentrations in

*e-mail: lpzhang@zju.edu.cn ground and surface waters is $\mathrm{P}$ loss resulting from the unreasonable application of phosphate fertilizer and the serious erosion of water and soil $[3,4]$. Due to the contradiction between population growth and food demand, many sloping lands have been reclaimed as cultivated lands for planting crops and vegetables [5]. The interference of artificial farming has aggravated soil erosion and loss of nutrients such as nitrogen $(\mathrm{N})$ and $\mathrm{P}$ on the slopes, which has reduced the efficiency of 
nutrient utilization [6]. Soil erosion on sloping land is a worldwide environmental concern that causes a decline in productivity of sloping lands and deterioration of soil quality [7, 8]. The discharged nutrients would enter the receiving water bodies like rivers and lakes through surface runoff and subsurface flow to accelerate eutrophication $[9,10]$. Studying the nutrient loss pathways at the source of water pollution on the sloping land and conducting reasonable management like control measures can significantly improve soil and water conservation, reduce nutrient loss, and increase soil fertility as well as crop yield [11-13].

There are many factors affecting the $\mathrm{P}$ loss from the sloping land, including rainfall characteristics, topographic conditions like slope gradient and slope length, fertilizer type and amount, soil properties like texture and organic matter content, surface land cover and wildfires, farming practices, land type and utilization method [14-19]. Rainfall intensity and slope gradient impact the $\mathrm{P}$ loss by directly affecting runoff and sediment yield. Most studies have shown a positive correlation between rainfall intensity and nutrient loss $[20,21]$. There are two main pathways for soil nutrient loss that alternate under different rainfall conditions, including runoff and sediment. Some studies have pointed out that $\mathrm{P}$ loss is mainly caused by sediment transportation [22]. Other studies believe that P loss is dominated by surface runoff [23]. The proportion of soluble nutrient loss with runoff is high when rainfall intensity is small, but soil nutrients dominantly migrate with sediment when rainfall intensity is heavy. The amount of nutrient loss with soil normally increases with increasing slope gradient, but the loss amount decreases when the slope gradient is greater than a certain value, that is, there exists a critical slope gradient for nutrient loss [24, 25].

As discussed above, most studies on nutrient loss from sloping farmland focus on surface runoff and sediment, and the loss mechanism is relatively well understood. However, research on the mechanism of nutrient loss via subsurface flow is still at an exploratory stage, especially that the dynamics of the $\mathrm{P}$ migration within soil are very complex and difficult to be studied [26]. The reason why the $\mathrm{P}$ output through subsurface flow is less abundant is very vague and ambiguous, and the main factors influencing P loss via subsurface flow are not clearly distinguishable. Previous studies have found that the characteristics of subsurface flow and surface runoff are significantly different [27, 28]. Subsurface flow within the soil lags behind surface flow and it takes more yielding time even long after the rainfall event stops. It has also been found that subsurface flow accounts for more than half of the total runoff volume [29, 30], which is an important form of rainfall runoff. Subsurface flow can not only change the relationship between rainfall intensity and runoff but also affect the loss of nutrients. Studies have shown that soil leaching intensity is strong in areas with abundant precipitation and makes the formation of leaching and sediment layers in the soil profile, which affects the effective porosity of the soil and its ability to transport nutrients [31]. The migration of nutrients with the downward seepage flow is affected by the physical structure and material interactions of the soil and the characteristics of rainfall infiltration [32, 33].

Most of the studies about $\mathrm{P}$ loss from sloping lands in China mainly focus on the discussion of loess, red and purple soils [34-36]. There are few studies about the effects of slope gradient and rainfall intensity on soil erosion and nutrient loss on the weathered granite slopes. The soils developed from the parent materials of weathered granite are widely distributed in the central and southeastern parts of China, where they are easily exposed to water erosion caused by rainfall with high hilly alpine terrain [37]. Therefore, it is of great significance to investigate the $\mathrm{P}$ loss characteristics and main loss pathways for soil and water conservation. Due to high operational costs and measurement difficulties, there is not enough in-site monitoring data suitable for effective mitigation and control of environmental nutrients in the weathered granite area. Therefore, an experimental study with two slope gradients and four rainfall intensities was conducted to investigate the characteristics of $\mathrm{P}$ loss processes. The objectives of the present work are (1) to investigate the effects of rainfall intensity and slope gradient on soil erosion and $\mathrm{P}$ loss processes, (2) to study the main loss forms of $\mathrm{P}$ and their contributions, and (3) to reveal the main loss pathways of $\mathrm{P}$ under different experimental conditions.

\section{Material and Methods}

\section{Soil Samples}

The soil was collected from Anji County $\left(30^{\circ} 34^{\prime} \mathrm{N}\right.$, $119^{\circ} 23^{\prime}$ E) in northwestern Zhejiang Province. The soil derived from the laterite layer mainly developed from the parent materials of weathered granite, which is typical and representative of the study area of southeast China. The soil is weakly acidic with an average bulk density of $1.60 \mathrm{~g} / \mathrm{cm}^{3}$. The total phosphorus content is $1.45 \mathrm{~g} / \mathrm{kg}$ with available phosphorus content of $87.20 \mathrm{mg} / \mathrm{kg}$. The total nitrogen and organic matter content are $0.61 \mathrm{~g} / \mathrm{kg}$ and $4.34 \mathrm{~g} / \mathrm{kg}$, respectively. The particle fraction distribution is $11.14 \%$ for clay $(<-0.002 \mathrm{~mm})$, $14.71 \%$ for silt $(0.002-0.02 \mathrm{~mm})$ and $74.15 \%$ for sand (0.02-2 mm), which is typical for sandy loam.

The soil was moved and put into the soil tanks with the method of original state removal. The soil was collected in-site from the surface to the deeper layers at every $5 \mathrm{~cm}$ for bagging and a total of 12 layers, which was $60 \mathrm{~cm}$ in thickness was stratified for soil bulk density test. Then the soil was filled in the soil tanks with a corresponding layer order to ensure the consistency of natural soil bulk density. The soil tanks were set aside for a period to allow the soil to sink naturally and regain its natural characteristics before starting a rainfall test. 
The time interval between two tests was one week. Soil samples were taken and the soil moisture content was determined to ensure that the initial moisture content of the test soil was the same before each rainfall test. The mixing fertilizers of $100 \mathrm{~g}$ organic fertilizer $\left(\mathrm{m}\left(\mathrm{P}_{2} \mathrm{O}_{5}\right)=3.5 \%\right)$ and $20 \mathrm{~g}$ compound fertilizer $\left(\mathrm{m}(\mathrm{N}): \mathrm{m}\left(\mathrm{P}_{2} \mathrm{O}_{5}\right): \mathrm{m}\left(\mathrm{K}_{2} \mathrm{O}\right)=15 \%: 15 \%: 15 \%\right)$ were applied to make soil fertility equal. After finishing a rainfall test, the surface-eroded soil on the top $5 \mathrm{~cm}$ layer was replaced by new original soil for the next test.

\section{Experimental Design}

The simulated rainfall experiments were conducted in the Agricultural Science Experimental Station of Zhejiang University (Changxing County, China). The rainfall intensity was regulated by a QYJY-502 portable automatic rainfall simulator (Fig. 1a) with a range of $15 \sim 200 \mathrm{~mm} / \mathrm{h}$. The spray nozzles of the simulator were set $6 \mathrm{~m}$ above the soil tanks with a coverage of $4 \mathrm{~m} \times 4 \mathrm{~m}$, which was enough for the majority of the raindrops to achieve terminal velocities like natural rainfall. A kind of three-dimensional analog soil tank (Fig. 1b) with variable-slope that could be flexibly adjusted within the range of $0^{\circ}$ to $30^{\circ}$ was adopted as the experiment runoff plot, the geometry size of which is $2.0 \mathrm{~m}$ length $\times 1.0 \mathrm{~m}$ width $\times 0.6 \mathrm{~cm}$ depth. Two soil tanks were arranged separately in parallel with the same rainfall intensity, covered simultaneously so that the results could be calculated repeatedly. An extension groove of $3 \mathrm{~cm}$ in height with a metal mesh of small aperture in the interior was set at the front and the left and right sides at the middle and bottom of the soil tanks for the convenient collection of subsurface flow.
The surface flow and sediment were collected through the front groove with a triangular outlet at the top of the soil tanks.

Rainfall intensity should be calibrated after covering the soil tanks with a waterproof cloth before each rainfall test. After reaching the target rainfall intensity and verifying the uniformity coefficient which was above $85 \%$ and was acceptable, the waterproof cloth was removed and timing was started. The time at which the surface flow and subsurface flow occurred was recorded. The total time for surface flow and sediment collection on the slopes was 90 min after the occurrence of surface flow. The total rainfall duration ranged from the beginning of effective rainfall to the completion of the surface flow collection. The sampling time was at every 3 min and the muddy runoff volume was measured with a cylinder. About $250 \mathrm{~mL}$ of the muddy runoff samples were collected and brought to the laboratory as soon as possible for water quality test. The remaining samples were set aside for at least $24 \mathrm{~h}$ and clear supernatant was decanted from the containers. Then the wet sediment was air dried for the weight and further analysis. The total phosphorus (TP) of the eroded sediment was measured by molybdenum blue colorimetry after digestion with $\mathrm{HClO}_{4}-\mathrm{H}_{2} \mathrm{SO}_{4}$. The muddy runoff samples were shaken and then some of them were digested by potassium persulfate oxidation to determine the TP concentration, and others were filtered by $0.45-\mu \mathrm{m}$ microporous membrane to determine the dissolved phosphorus (DP) concentration with the method of UV/VIS spectrophotometric. The difference between TP and DP content was considered as particulate phosphorus (PP) with the organic phosphorus in the filtered samples assumed to be negligible. All the
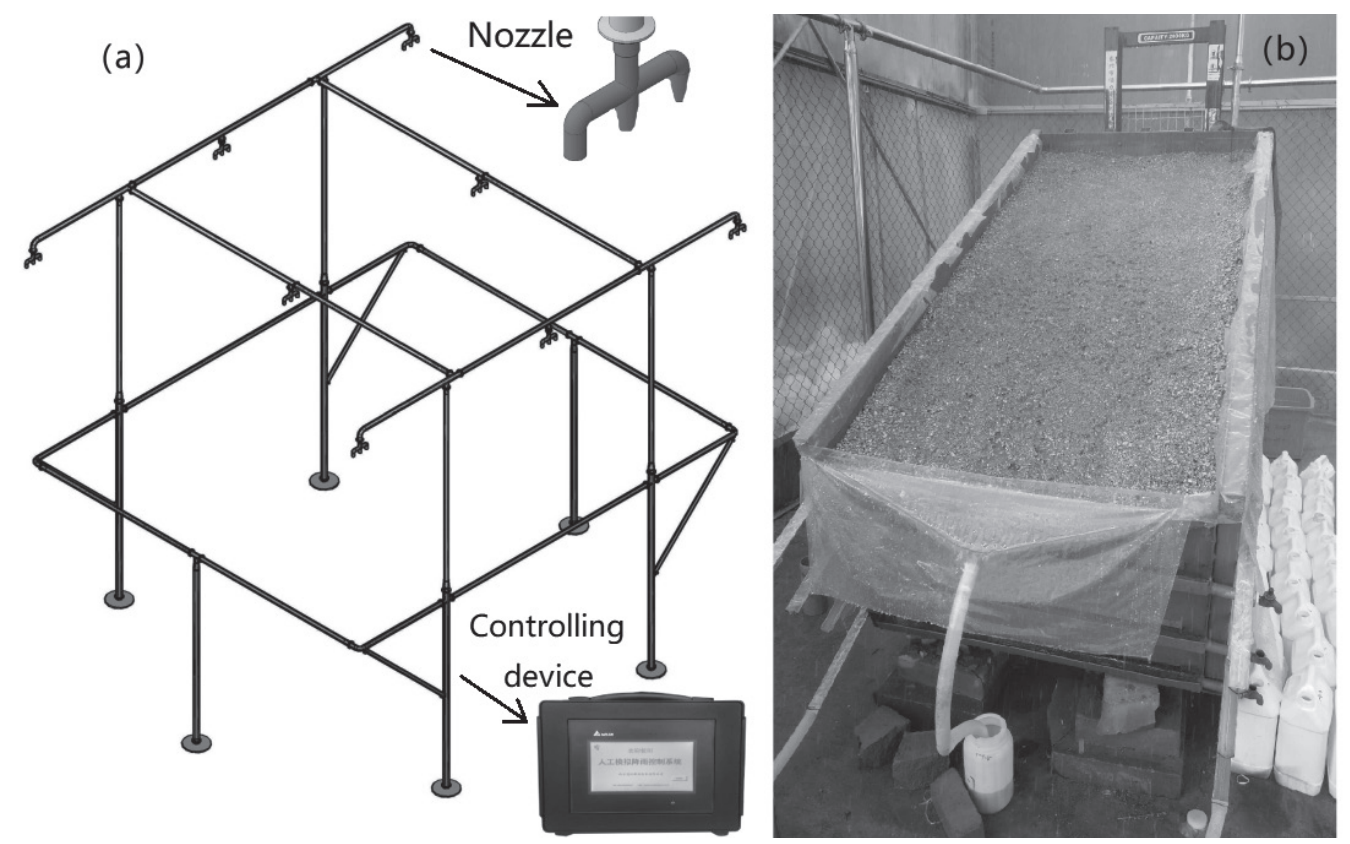

Fig. 1. Artificial rainfall simulating system and equipment including a) artificial rainfall simulator with controlling device and b) soil tanks. 
P loss concentration and amount were the average of the two repeated treatments.

\section{Data Analysis and Calculation}

Both SPSS20.0 and Origin9.0 were used for statistical and cartographic analysis of data. The formulas for calculating the accumulative P loss amount in the runoff and sediment of each form were as follows:

$$
W_{r}=\sum_{i=1}^{n} \rho_{r_{i}} \times v_{i} W_{s}=\sum_{i=1}^{n} \rho_{s i} \times m_{i}
$$

...where $W_{r}$ and $W_{s}$ are respectively the TP loss amount in the runoff and sediment during the rainfall, $\mathrm{g} ; \rho_{r i}$ and $\rho_{s i}$ are respectively the average $\mathrm{P}$ concentration of the i sampling event (3 min), $\mathrm{mg} / \mathrm{L}$ for runoff and $\mathrm{mg} / \mathrm{kg}$ for sediment; $v_{i}$ is the runoff volume collected between sampling event i-1 and sampling event $\mathrm{i}, \mathrm{mL} ; m_{i}$ is the sediment mass collected between sampling event $i-1$ and sampling event $\mathrm{i}, \mathrm{g}$; and $\mathrm{i}=1$ to $\mathrm{n}$ is the sampling events of runoff and sediment during the experimental period, $\mathrm{n} \leq 60$.

\section{Results and Discussion}

\section{Runoff, Sediment Yield and P Loss in Surface Flow}

The variations of runoff, sediment yield and $\mathrm{P}$ loss concentrations in the surface flow with the prolongation of rainfall are depicted in Fig. 2. The runoff yield showed an overall increasing trend with rainfall duration under the rainfall intensities of $1.0 \mathrm{~mm} / \mathrm{min}$ and $1.5 \mathrm{~mm} / \mathrm{min}$, while there were short increasing periods under the larger rainfall intensities and then the runoff yield became relatively stable. Overall, the sediment yield transported by the surface flow decreased with the prolongation of rainfall. But short increments of high sediment content existed in the early stage under rainfall intensities larger than $1.0 \mathrm{~mm} / \mathrm{min}$, which could be called the first flush effect [2], leading to the peaking values of sediment yield. The short increasing trends and fluctuations might be caused by the rainfall splashes, which could break the soil aggregates [38]. As the rainfall continued, the sediment yield would be limited by the detaching limitation after the fine mobilizable particles of the topsoils were mostly transported and the protecting effect of a mixed soilrunoff layer appeared on the surface [39]. The mixed layer could not only dissipate the raindrop energy but also protect the soil particles in the deeper soil layers, which could not be activated and transported until the runoff intensity was strong enough [40]. The runoff yield on the $8^{\circ}$ slope was greater than that on the $15^{\circ}$ slope under the same rainfall intensities, while the sediment yield showed an opposite trend. The reason might be that the rain-bearing area became smaller and the velocity of surface flow became larger due to increased shear stress. The remaining time of surface flow on the slopes became shorter and weakened the protecting effect of the mixed layer, making a stronger effect of rainfall splashing on the topsoil [24]. On the one hand, the increased effect of raindrop splashing could distinctly activate and transport more soil particles and result in more sediment yield. On the other hand, the raindrop splashing could make the topsoil on the slopes rugged, which was beneficial to infiltration of surface flow.

The loss concentrations of TP, DP and PP decreased with the rainfall duration under different rainfall intensities on the $8^{\circ}$ and $15^{\circ}$ slopes. The first flush effect also occurred on the $8^{\circ}$ slope for $\mathrm{P}$ concentrations but it was a little different to that of sediment as there was a decline before the increasing trend. Most of the peaking values of $\mathrm{P}$ concentration appeared in the first sample, which was related to the high $\mathrm{P}$ content and small runoff in the initial stage on the topsoil. When the runoff volume became larger, the $\mathrm{P}$ concentration would become small due to the dilution effect. In addition, the decline of $\mathrm{P}$ loss concentration with rainfall duration may reflect an exhaustion of readily mobilizable P sources [41]. However, the average P loss concentrations in surface flow increased significantly with the increasing rainfall intensity. The average loss concentrations of TP in the surface flow on the $15^{\circ}$ slope under different rainfalls were respectively $0.73,1.18$, $1.43,1.72 \mathrm{mg} / \mathrm{L}$, while that under the corresponding similar rainfalls on the $8^{\circ}$ slope were respectively 0.97 , $1.42,1.72,1.80 \mathrm{mg} / \mathrm{L}$, which were about 1.20 times that of the $15^{\circ}$ slope.

As discussed above, runoff yield in surface flow was greater on the gentle slope $\left(8^{\circ}\right)$ and remained so for a longer time, so $\mathrm{P}$ contained in the soil was more likely to be dissolved in the runoff and could be carried away. The DP loss concentrations showed the similar changing trend to TP loss concentrations with rainfall duration, but the average DP loss concentrations under different treatments increased with rainfall intensities and decreased with slope gradient with slight fluctuations. The loss concentrations of PP in the surface flow were overall less than the DP loss concentrations and fluctuated wildly. The average loss concentrations of DP in the surface flow on the $15^{\circ}$ slope under different rainfall intensities were respectively $0.45,0.84,0.96$, $1.35 \mathrm{mg} / \mathrm{L}$, which were about 2.41 times that of the PP average loss concentrations. The $\mathrm{DP} / \mathrm{PP}$ ratio on the $8^{\circ}$ slope was about 2.43 . It could be concluded that DP was the main P loss pattern in surface flow, which accounted for 54.32-78.51\% under different experimental treatments. The findings were similar with that of Heathwaite and Dils [42], who found the predominance of the DP fraction in surface flow. Drewry et al. [43] also found that rainfall intensity had a significant impact on $\mathrm{P}$ loss through rainstorm monitoring and load estimation in the Tuross River Basin of Australia, and the nutrient 

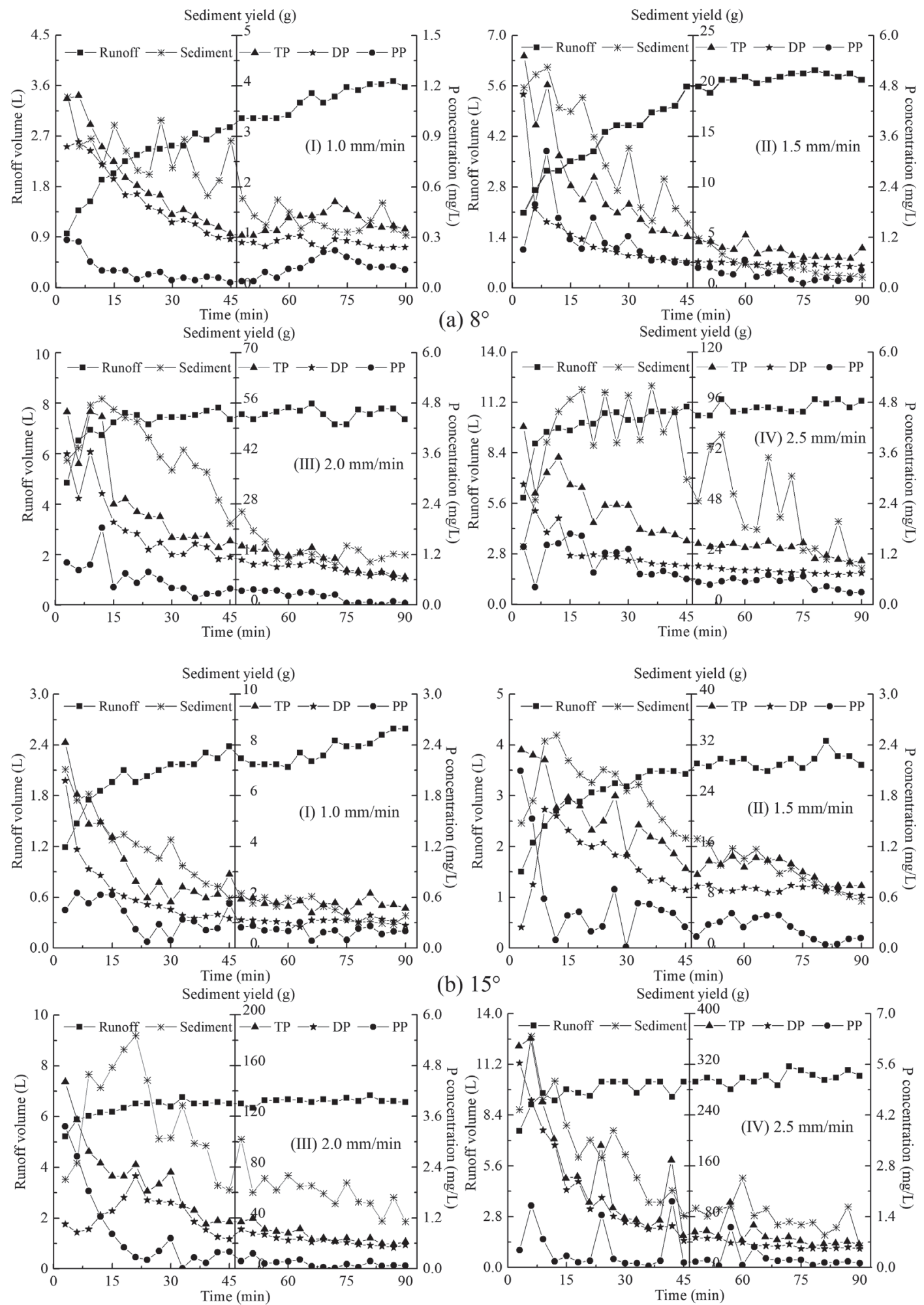

Fig. 2. Runoff, sediment yield and P loss via surface flow under different rainfall intensities on the a) $8^{\circ}$ and b) $15^{\circ}$ slopes.

loss under small rainfall intensity was mainly in dissolved form. However, many other previous studies found that the major part of TP loss via surface flow was accounted for by PP [2, 44-46], which could be adsorbed in soil particles and mobilized by rainfall runoff. This was consistent with laboratory experiments of $\mathrm{P}$ loss with surface runoff reported by Wang et al. [47], with most of $\mathrm{P}$ transformed through sediment loss. The reason for the differences might be that the $\mathrm{P}$ loss via sediment in this study has not been take into consideration when comparing the loss patterns in this section, so it will be analyzed latter. 


\section{Runoff and P Loss in Subsurface Flow}

The changing trends of runoff and $\mathrm{P}$ loss concentrations with rainfall duration in subsurface flow were significantly different from that in surface flow (Fig. 3). It could be seen from the unimodal curve that the runoff yield increased first up to the maximum values and then decreased with the prolongation of rainfall duration under different experimental treatments. Runoff yield on the steep slope $\left(15^{\circ}\right)$ was more than that on the gentle slope $\left(8^{\circ}\right)$ under the same rainfall intensities. The peaking time for the $8^{\circ}$ and $15^{\circ}$ slopes were respectively about $30 \mathrm{~min}$ and $60 \mathrm{~min}$ after the occurrence of subsurface flow. The peaking time at which the subsurface flow reached the maximum was relatively delayed as the rainfall intensity increased on both the steep and gentle slopes. The main factors affecting runoff yield included antecedent moisture, slope gradient, soil porosity, rainfall intensity and duration [48, 49]. The infiltration rate was faster at the beginning under the rainfall intensities of 1.0 and $1.5 \mathrm{~m} / \mathrm{min}$ due to the coarse surface of topsoil with
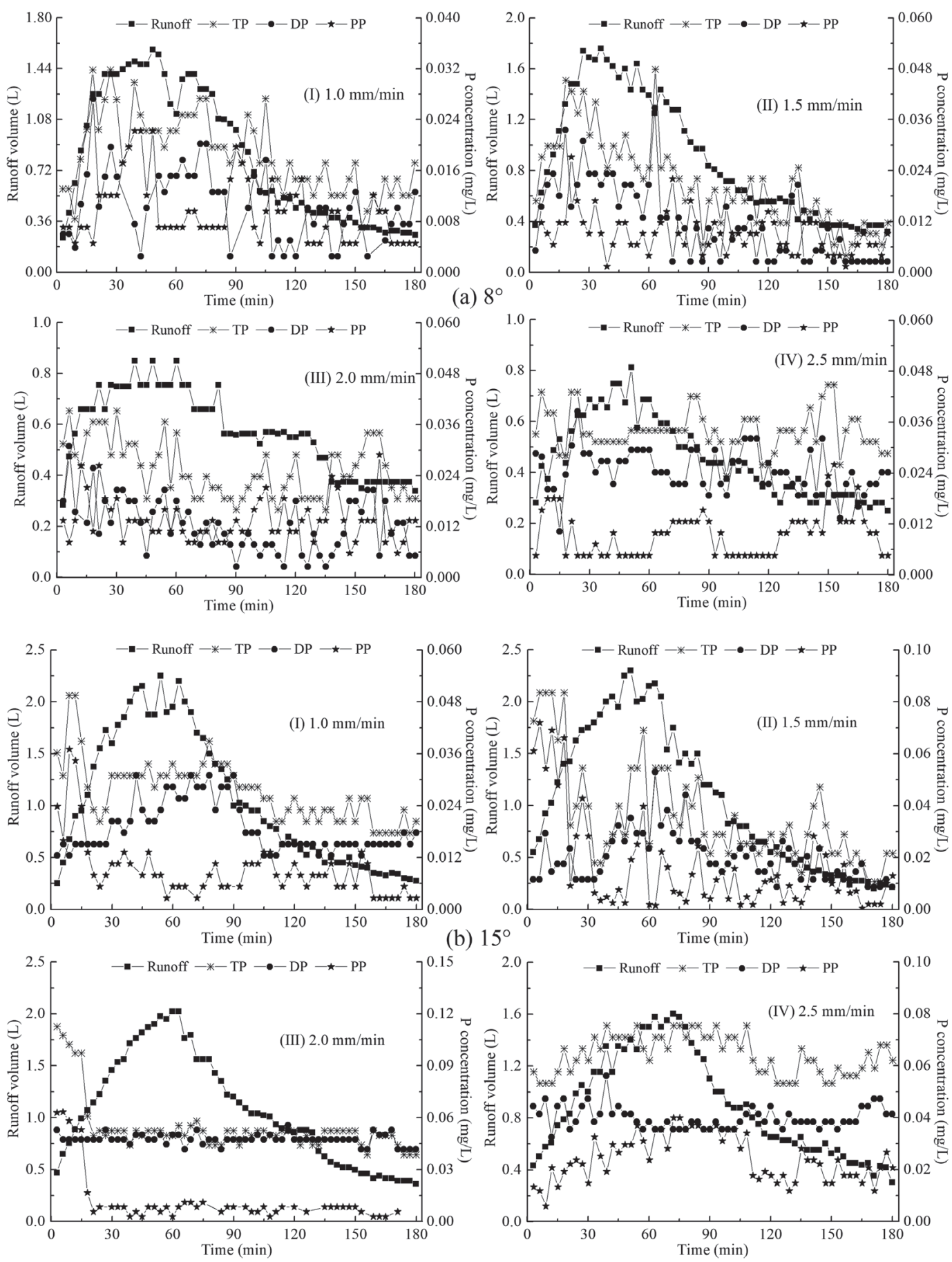

Fig. 3. Runoff and P loss via subsurface flow under different rainfall intensities on the (a) $8^{\circ}$ and (b) $15^{\circ}$ slopes. 
large particles, which resulted in the relatively large effective soil porosity. Then the test soil gradually reached saturation and the runoff yielded by mechanism of excess storage with the rainfall infiltration was less than that in the previous period, during which the main pattern of rainfall runoff was surface flow rather than subsurface flow. When rainfall intensity approached to beyond a certain range, including 2.0 and $2.5 \mathrm{~mm} / \mathrm{min}$, the fine particles of the test soil would be transported either vertically to fulfill the infiltration pores or horizontally to out of the soil tanks at the initial stage of rainfall. The topsoil on the slopes was easy to crust, which could weaken the rainfall infiltration and facilitate the yield of surface flow generated by excess infiltration. At the same time, the infiltration intensity was less than rainfall intensity and the main pattern of rainfall runoff was surface flow that was much more than subsurface flow. This feature was particularly noticeable under heavy rainfall conditions like rainfall intensity of $2.5 \mathrm{~mm} / \mathrm{min}$.

The P loss concentrations in subsurface flow showed great fluctuations with rainfall duration under different conditions because the runoff beneath the topsoil moved a longer path. The average TP loss concentrations under different rainfall intensities on the $15^{\circ}$ slope were respectively $0.029,0.039,0.053$, and $0.067 \mathrm{mg} / \mathrm{L}$, which increased with rainfall intensity and were about 1.39-2.07 times that of the $8^{\circ}$ slope. On the $8^{\circ}$ slope, TP loss concentrations first increased and then decreased with the prolongation of rainfall duration under the rainfall intensities of 1.0 and $1.5 \mathrm{~mm} /$ min, but it showed an upward trend finally under the rainfall intensities of 2.0 and $2.5 \mathrm{~mm} / \mathrm{min}$. The curve of TP loss concentrations on the $15^{\circ}$ slope exhibited many peaks under the rainfall intensities of 1.0 and $1.5 \mathrm{~mm} / \mathrm{min}$ while it showed a short decreasing stage and then became stable under the rainfall intensities of $2.0 \mathrm{~mm} / \mathrm{min}$. When the rainfall intensity increased to $2.5 \mathrm{~mm} / \mathrm{min}$, the changing ranges of TP loss concentration on the $15^{\circ}$ slope were relatively small with slight fluctuations. DP and PP loss concentrations showed no obvious regularity for varying trends under different rainfall intensities, and the changes of DP loss concentration were more similar with those of TP loss concentration. DP loss concentrations on the $15^{\circ}$ slope were greater than that on the $8^{\circ}$ slope, while PP loss concentration fluctuated dramatically on different slopes. DP loss concentrations on the $15^{\circ}$ slope were greater than PP loss concentrations, while it showed an opposite tendency on the $8^{\circ}$ slope. The reason might be that the faster percolation on the $15^{\circ}$ slope maximized the interaction between water and soil matrix [33], while the $\mathrm{P}$ loss concentrations on the $8^{\circ}$ slope operated in a manner similar with the surface flow with slow flow mechanisms minimizing the water-soil interaction [50]. Based on the above results, it could be concluded that both the runoff yield and $\mathrm{P}$ loss concentrations in subsurface flow were much less than that in surface flow, and showed great fluctuations under different conditions. However, the P loss via subsurface flow could not be overlooked as the $\mathrm{P}$ loss concentrations were almost larger than the threshold value of $0.02 \mathrm{mg} / \mathrm{L}$, which was a limited factor that could induce water eutrophication [46]. The $\mathrm{P}$ adsorption as well as desorption mechanisms between runoff and soil particles need to be further studied.

Under the experimental conditions, the P loss amount increased gradually as rainfall intensity increased. When rainfall intensity exceeded up to $1.5 \mathrm{~mm} / \mathrm{min}$ or $2.0 \mathrm{~mm} / \mathrm{min}$, the P loss started to decrease, making the $\mathrm{P}$ loss reach the maximum under rainfall intensity of $1.5 \mathrm{~mm} / \mathrm{min}$ or $2.0 \mathrm{~mm} / \mathrm{min}$, which was consistent with the variation of subsurface flow volume in the soils. Under the conditions of small rainfall intensity, the soil infiltration capacity was strong and the runoff rate in the soils increased gradually with the increasing rainfall intensity. When rainfall intensity exceeded $1.5 \mathrm{~mm} / \mathrm{min}$, the finer soil particles on the slopes would block the soil pores of the infiltrated water flow or form a sediment layer in the profile under the effect of raindrops, which hindered the movement of the subsurface flow so that the flow volume and nutrient loss in the soils were reduced. Overall, the effect of rainfall intensity on P loss in the soils was indirect mainly by affecting the runoff volume. Due to the large bulk density of the tight-tested soil, the PP loss amount via subsurface flow with the infiltration of rainwater was less and the runoff rate in the soils, which increased with increasing slope gradient. The large amount of infiltration directly promoted the DP loss with subsurface flow. That increment would eventually increase the ratio of DP/TP loss as the slope gradient increased and the ratio of DP/TP loss in the soil was almost greater than $50 \%$. Therefore, the main loss pattern of $\mathrm{P}$ in the soils via subsurface flow was not obviously affected by rainfall intensity and slope gradient, and was mainly lost in the form of DP under the simulated rainfall conditions.

\section{Accumulative Runoff, Sediment and P Losses}

Previous studies have concluded that $\mathrm{P}$ loss from sloping land was closely associated with not only topographic factors such as slope gradient and slope length but also rainfall factors like pattern, intensity and duration [24, 51]. Runoff and sediment were inseparable because runoff was the carrier of eroded sediment and both runoff and sediment induced by rainfall played very important roles in transporting nutrients. Fig. 4 showed the accumulative runoff volume and sediment yield under different experimental treatments. It could be seen that the surface flow volume increased with the increment of rainfall intensity on the $8^{\circ}$ and $15^{\circ}$ slopes, while the subsurface flow volume first increased and then decreased with crest values under the rainfall intensity of $1.5 \mathrm{~mm} / \mathrm{min}$. The subsurface flow volume on the steep slope was greater than that on the gentle slope, while the surface flow volume exhibited an opposite tendency. The accumulative sediment yield 


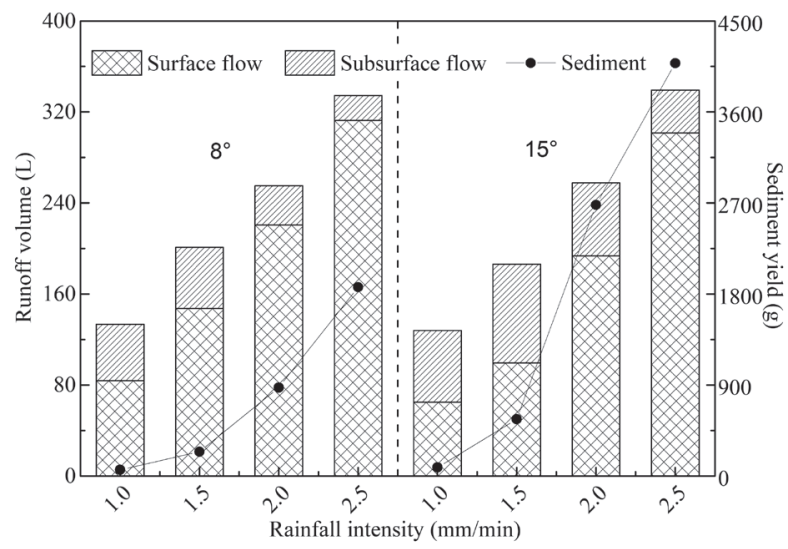

Fig. 4. Accumulative runoff, sediment yield under different experimental treatments.

increased with both rainfall intensity and slope gradient. Runoff scouring was the main driving force of sediment loss, and slope gradient was one of the most important factors affecting sediment yield $[6,52]$. The sediment yield under different rainfall intensities on the $15^{\circ}$ slope were respectively about $1.40,2.34,3.07$ and 2.19 times as much as that on the $8^{\circ}$ slope. These results were similar with the findings by $\mathrm{Wu}$ et al. [18] that the influence of slope gradient on sediment yield decreased considerably with increasing rainfall intensity.

Based on the runoff, sediment yield and TP loss concentrations, the accumulative TP loss load via different pathways under the experimental treatments was calculated and summarized. It could be seen from Fig. 5 that the varying regularity of TP loss on the weathered granite slops was to some extent similar with most of the previous studies, as the loss of TP transported by sediment was the main pathway of P loss [47]. Surface flow attributed secondly to the TP loss load followed by subsurface flow as the least. Under the same rainfall intensity, the accumulative TP loss load via surface flow and sediment on the $8^{\circ}$ slope was greater than that on the $15^{\circ}$ slope, while

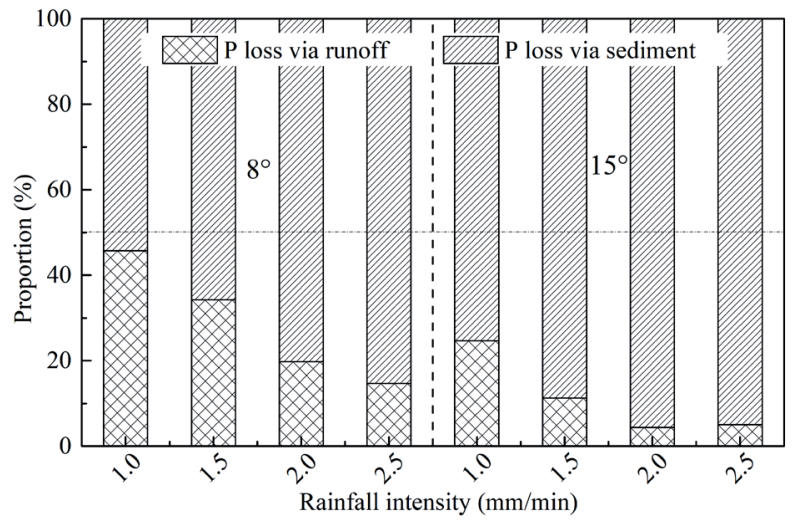

Fig. 5. Fractions of accumulative TP loss load via different pathways under different treatments.

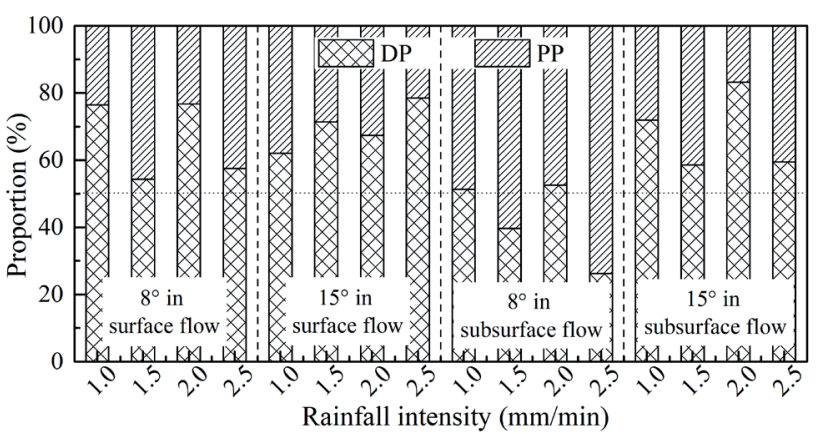

Fig. 6. Fractions of DP and PP loss load in surface flow and subsurface flow under different treatments.

the accumulative TP loss load via subsurface flow was much greater on the $15^{\circ}$ slope and the difference became larger with increasing rainfall intensity. The reason might be that $\mathrm{P}$ was more likely to be absorbed to the soil surface and then could be transported with eroded sediment along with rainfall runoff. Under the same slope gradient, the accumulative TP loss load via surface flow and sediment increased with increasing rainfall intensity, and the sediment transportation played a more important role in the accumulative TP loss load. The accumulative TP loss load obviously fluctuated in subsurface flow and even could be neglected compared to that in the sediment and surface flow. However, even though the loss load of TP in subsurface flow was small, the average loss concentration of DP in subsurface flow was relatively large (Fig. 6), which was still a threat to the water environment.

The proportions of DP in surface flow and subsurface flow were almost more than $50 \%$, except that under the intensities of 1.50 and $2.50 \mathrm{~mm} / \mathrm{min}$ on the gentle slopes, which indicated that DP was the main loss pattern of $\mathrm{P}$ loss via runoff. However, there was no strong regularity for variation trends of DP loss proportion under different rainfall intensities and slope gradients, and the changing ranges of DP loss proportion in subsurface flow were relatively larger than that in surface flow. Wu et al. [18] found the similar dramatic fluctuations of dissolved TP concentration in runoff on bare loess slopes and attributed this to the changes of splashing on soil surface that influenced the desorption capacity of soil P. It has been found that high $\mathrm{P}$ concentrations were recorded in surface flow with most $\mathrm{P}$ transported in the dissolved fraction [42]. Therefore, measures like vegetation and mulch, which could increase soil surface cover should be taken to reduce surface flow and sediment yield so as to hinder the loss of nutrients from the hillslopes into aquatic environments [53].

\section{Coupling Relationships of Runoff-Sediment-TP, DP and PP}

The recognition and control of none-point-source pollution, especially $\mathrm{N}$ and $\mathrm{P}$ loss, is the basic scientific 
problem and is of great significance for improving the water environment of China. The risk of $\mathrm{P}$ loss from sloping land is greater than previously thought, with both surface and subsurface hillslope hydrological pathways being important in $\mathrm{P}$ transport. However, one of the problems in understanding hydrological pathways of nutrient loss from land to streams is their dynamic characteristics. The coupling relationships of runoff-
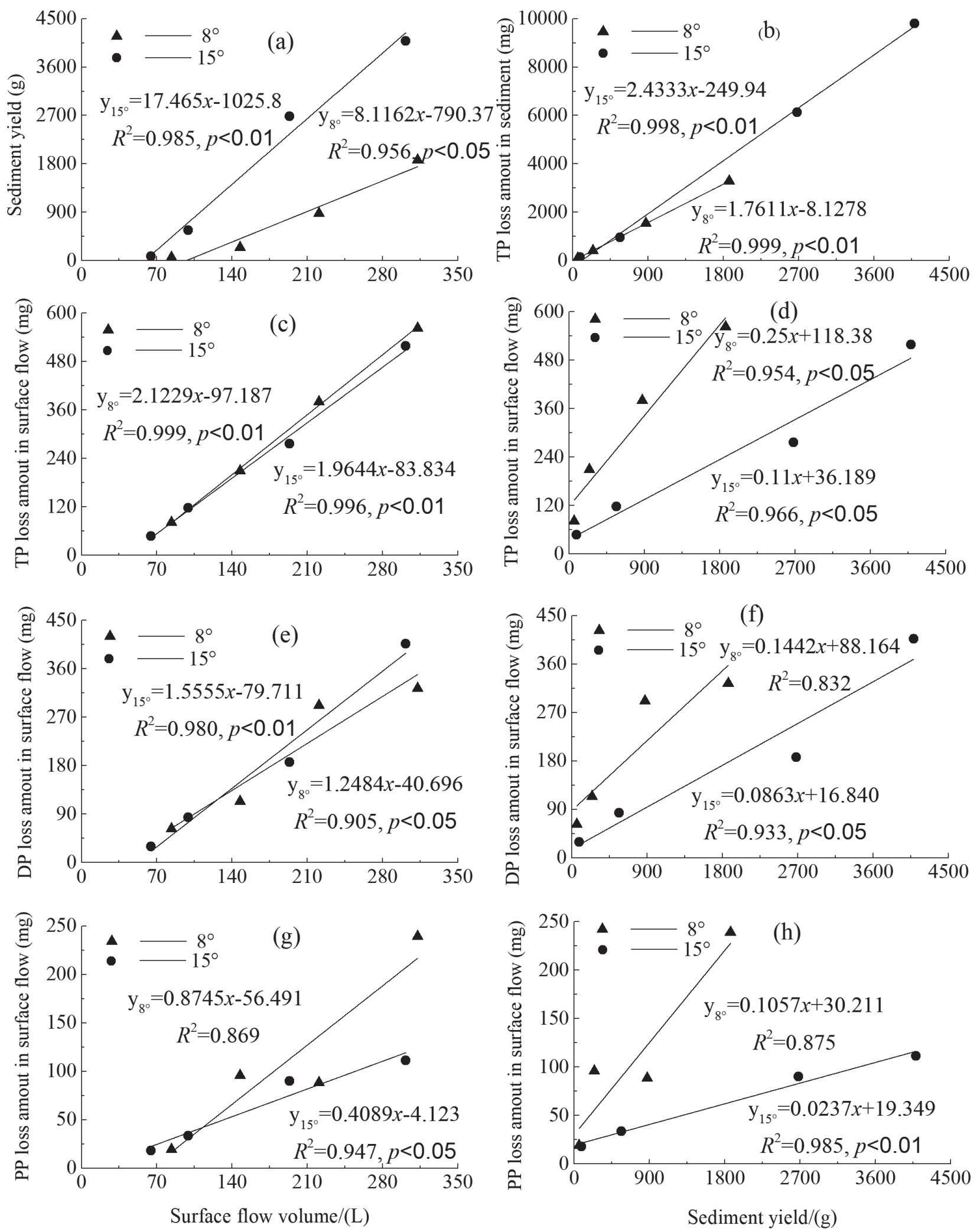

Fig. 7. Regression correlations between runoff-sediment-TP, DP and PP in surface flow on different slopes. 
Table 1. Coupling relations of runoff-TP, DP and PP loss load in subsurface flow

\begin{tabular}{|c|c|c|c|c|}
\hline & Slope gradient $\left(^{\circ}\right)$ & TP $(\mathrm{mg})$ & DP $(\mathrm{mg})$ & PP $(\mathrm{mg})$ \\
\hline Slope gradient $\left(^{\circ}\right)$ & 1 & $0.876^{* *}$ & $0.865^{* *}$ & 0.488 \\
\hline TP $(\mathrm{mg})$ & $0.876^{* *}$ & 1 & $0.959^{* *}$ & 0.636 \\
\hline DP $(\mathrm{mg})$ & $0.865^{* *}$ & $0.959^{* *}$ & 1 & 0.391 \\
\hline PP $(\mathrm{mg})$ & 0.488 & 0.636 & 0.391 & 1 \\
\hline
\end{tabular}

*Correlation is significant at a confidence level of $0.05, \mathrm{~N}=8$

** Correlation is significant at a confidence level of $0.01, \mathrm{~N}=8$

sediment-TP, DP and PP via surface flow and subsurface flow were analyzed with SPSS21.0 to explore their inner quantitative relations. Fig. 7 shows that sediment yield was significantly correlated with surface flow volume, which was significantly correlated with rainfall intensity $\left(\mathrm{R}^{2}>0.956\right)$. When the runoff yield was the same, sediment yield on the steep slope was greater than that on the gentle slope. Exponential functions could be used to describe the positive relationship between sediment yield $(W, \mathrm{~g})$ and rainfall intensity $(I, \mathrm{~mm} / \mathrm{min})$ on the $8^{\circ}$ slope $\left(W=57.614 I^{3.808}, \mathrm{R}^{2}=0.997\right)$ and $15^{\circ}$ slope $\left(W=92.215 I^{4.407}, \mathrm{R}^{2}=0.982\right)$. The TP loss load in the sediment on the steep slope was also greater than that on the gentle slope when the sediment yield was the same. TP loss load in sediment showed a liner correlation with sediment yield $\left(\mathrm{R}^{2}>0.998\right)$ and was significantly correlated with rainfall intensity and surface flow volume. TP, DP and PP loss loads in surface flow were all positively correlated with surface flow volume $\left(\mathrm{R}^{2}>0.869\right)$ as well as sediment yield $\left(\mathrm{R}^{2}>0.832\right)$, though this was partly due to the fact that runoff volume was used to calculate the P loss load [2]. The accumulative TP loss load in both runoff and sediment showed a positive power relationship with rainfall intensity $\left(\mathrm{R}^{2}>0.982\right)$. Rainfall intensity resulted in soil detachment and enhanced eroded sediment and nutrient transport [54]. Wang et al. believed that nutrient loss via sediment was significantly affected by soil erodibility [3]. TP and DP loss load in subsurface flow showed a significant correlation with slope gradient (Table 1). DP loss load also showed a significantly correlation with TP loss load as it was the main loss form of TP lost in the subsurface flow.

\section{Conclusions}

This study focused on the soils derived the parent materials of weathered granite to systematically explore the characteristics of $\mathrm{P}$ loss from the sloping land with the method of indoor artificial simulated rainfall. Results indicated that surface flow increased with rainfall duration while subsurface flow showed an increasing-decreasing trend. Sediment yield generally decreased with short increasing trends in the early stage under large rainfall intensities. The loss concentrations of TP, DP and PP decreased in surface flow and greatly fluctuated in subsurface flow under different experimental conditions. The average loss concentration of TP in surface flow on the $8^{\circ}$ slope was about 1.20 times that of the $15^{\circ}$ slope, while that in the subsurface flow on the $15^{\circ}$ slope was about 1.39 2.07 times that of the $8^{\circ}$ slope. DP loss concentrations in both surface flow and subsurface flow showed a similar changing trend to TP. PP loss concentration in surface flow was overall less than the DP, and fluctuated wildly. It could be concluded that DP was the main $\mathrm{P}$ loss pattern in surface flow that accounted for 54.32-78.51\%. DP and PP loss concentrations in subsurface flow showed no obvious varying regularity. Both runoff yield and $\mathrm{P}$ loss concentrations in subsurface flow were much less than that in surface flow and showed great fluctuations. The main P loss pattern via subsurface flow was also DP, and it could not be overlooked.

We found that $\mathrm{P}$ transported by eroded sediment was the main P loss pathway with the contributing order as follows: eroded sediment $>$ surface flow $>$ subsurface flow. The correlation analysis of runoff-sediment-TP, DP and PP showed that sediment yield was significantly correlated with rainfall intensity and surface flow yield. TP, DP and PP loss loads in surface flow were all positively correlated with rainfall intensity and runoff yield as well as eroded sediment. The accumulative TP loss load in both runoff and sediment showed a positive power relationship with rainfall intensity. TP and DP loss load in subsurface flow presented a significant correlation with slope gradient, and DP loss load was significantly correlated with TP loss load. These results may provide scientific support for the control and mitigation of $\mathrm{P}$ pollution in the weathered granite area.

\section{Acknowledgements}

This work was supported by the National Natural Science Foundation of China (41877065).

\section{Conflict of Interest}

The authors declare no conflict of interest. 


\section{References}

1. NOVAIS S.V., OLIVIEIRA ZENERO M.D., CARNEIRO BARRETO M.S., MONTES C.R., PELEGRINO CERRI C.E. Phosphorus removal from eutrophic water using modified biochar. Sci. Total Environ. 633, 825, 2018.

2. ZHANG R., LI M., YUAN X., PAN Z. Influence of rainfall intensity and slope on suspended solids and phosphorus losses in runoff. Environ. Sci. Pollut. R. 26, 33963, 2018.

3. WANG G., WU B., ZHANG L., JIANG H., XU Z. Role of soil erodibility in affecting available nitrogen and phosphorus losses under simulated rainfall. J. Hydrol. 514, 180, 2014

4. FISCHER P., POETHIG R., GUCHER B., VENOHR M. Phosphorus saturation and superficial fertilizer application as key parameters to assess the risk of diffuse phosphorus losses from agricultural soils in Brazil. Sci. Total Environ. 630, 1515, 2018

5. PHILLIPS C.P. Reclaiming the erosion susceptible landscape of the Italian badlands for arable cultivation. Land Degrad. Dev. 9, 331, 1998.

6. EL KATEB H., ZHANG H., ZHANG P., MOSANDL R. Soil erosion and surface runoff on different vegetation covers and slope gradients: A field experiment in Southern Shaanxi Province, China. Catena. 105, 1, 2013.

7. HEWETT C.J.M., SIMPSON C., WAINWRIGHT J., HUDSON S. Communicating risks to infrastructure due to soil erosion: A bottom-up approach. Land Degrad. Dev. 29, 1282, 2018.

8. VALERA C.A., VALLE JUNIOR R.F., VARANDAS S.G.P., SANCHES FERNANDES L.F., PACHECO F.A.L. The role of environmental land use conflicts in soil fertility: A study on the Uberaba River basin, Brazil. Sci. Total Environ. 562, 463, 2016.

9. EGGEN R.I.L., HOLLENDER J., JOSS A., SCHAERER M., STAMM C. Reducing the discharge of micropollutants in the aquatic environment: The benefits of upgrading wastewater treatment plants. Environ. Sci. Technol. 48, 7683, 2014.

10. YANG P, LAI D.Y.F., JIN B., BASTVIKEN D., TAN L., TONG C. Dynamics of dissolved nutrients in the aquaculture shrimp ponds of the Min River estuary, China: Concentrations, fluxes and environmental loads. Sci. Total Environ. 603, 256, 2017.

11. DEELSTRA J., IITAL A., POVILAITIS A., KYLLMAR K., GREPSLAND I., BLICHER-MATHIESEN G., JANSONS V., KOSKIAHO J., LAGZDINS A. Hydrological pathways and nitrogen runoff in agricultural dominated catchments in Nordic and Baltic countries. Agr. Ecosyst. Environ. 195, 211, 2014.

12. BOURAIMA A., HE B., TIAN T. Runoff, nitrogen (N) and phosphorus (P) losses from purple slope cropland soil under rating fertilization in Three Gorges Region. Environ. Sci. Pollut. R. 23, 4541, 2016.

13. SANTOS R.M.B., SANCHES FERNANDES L.F., Pereira M.G., CORTES R.M.V., PACHECO F.A.L. A framework model for investigating the export of phosphorus to surface waters in forested watersheds: Implications to management. Sci. Total Environ. 536, 295, 2015.

14. HAHN C., PRASUHN V., STAMM C., SCHULIN R. Phosphorus losses in runoff from manured grassland of different soil P status at two rainfall intensities. Agr. Ecosyst. Environ. 153, 65, 2012.

15. NAPOLI M., MARTA A.D., ZANCHI C.A., ORLANDINI S. Assessment of soil and nutrient losses by runoff under different soil management practices in an Italian hilly vineyard. Soil Till. Res. 168, 71, 2017.

16. ZHANG Q., CHEN S., DONG Y., LIU D., YANG X., YANG Z. Controllability of phosphorus losses in surface runoff from sloping farmland treated by agricultural practices. Land Degrad. Dev. 28, 1704, 2017.

17. WANG Z., ZHANG T., TAN C., VADAS P., QI Z., WELLEN C. Modeling phosphorus losses from soils amended with cattle manures and chemical fertilizers. Sci. Total Environ. 639, 580, 2018.

18. WU L., QIAO S., PENG M., MA X. Coupling loss characteristics of runoff-sediment-adsorbed and dissolved nitrogen and phosphorus on bare loess slope. Environ. Sci. Pollut. R. 25, 14018, 2018.

19. SANTOS R.M.B., SANCHES FERNANDES L.F., Pereira M.G., CORTES R.M.V., PACHECO F.A.L. Water resources planning for a river basin with recurrent wildfires. Sci. Total Environ. 526, 1, 2015.

20. ZHANG G., LIU G., WANG G., WANG Y. Effects of vegetation cover and rainfall intensity on SedimentBound nutrient loss, size composition and volume fractal dimension of sediment particles. Pedosphere. 21, 676, 2011.

21. LIU R., WANG J., SHI J., CHEN Y., SUN C., ZHANG P., SHEN Z. Runoff characteristics and nutrient loss mechanism from plain farmland under simulated rainfall conditions. Sci. Total Environ. 468, 1069, 2014.

22. MCDOWELL R.W., NORRIS M., COX N. Using the provenance of sediment and bioavailable phosphorus to help mitigate water quality impact in an agricultural catchment. J. Environ. Qual. 45, 1276, 2016.

23. KLEINMAN P.J.A., SRINIVASAN M.S., DELL C.J., SCHMIDT J.P., SHARPLEY A.N., BRYANT R.B. Role of rainfall intensity and hydrology in nutrient transport via surface runoff. J. Environ. Qual. 35, 1248, 2006.

24. ZHAO Q., LI D., ZHUO M., GUO T., LIAO Y., XIE Z. Effects of rainfall intensity and slope gradient on erosion characteristics of the red soil slope. Stoch. Env. Res. Risk. A. 29, 609, 2015.

25. MAHMOODABADI M., SAJJADI S.A. Effects of rain intensity, slope gradient and particle size distribution on the relative contributions of splash and wash loads to raininduced erosion. Geomorphology. 253, 159, 2016.

26. SHOBER A.L., BUDA A.R., TURNER K.C., FIORELLINO N.M., ANDRES A.S., MC GRATH J.M., SIMS J.T. Assessing coastal plain risk indices for subsurface phosphorus loss. J. Environ. Qual. 46, 1270, 2017.

27. LIU Y., YANG J., HU J., TANG C., ZHANG H. Characteristics of the surface-subsurface flow generation and sediment yield to the rainfall regime and land-cover by long-term in-situ observation in the red soil region, Southern China. J. Hydrol. 539, 457, 2016.

28. LIU Q., ZHU B., TANG J., HUANG W., ZHANG X. Hydrological processes and sediment yields from hillslope croplands of Regosol under different slope gradients. Soil Sci. Soc. Am. J. 81, 1517, 2017.

29. XIE S., MO M., TU A., LIU Y. Characteristics of vertical runoff output on red-soil slope under natural rainfall condition. Trans. Chin. Soc. Agric. Eng. (Trans. of the CSAE), 30, 132, 2014 [In Chinese].

30. ZHENG H., HU J., HUANG P., WANG L., WAN J. Comparative study of nitrogen and phosphorus through surface-flow and interflow on red soil farmland. J. Soil Water Conserv. 28, 41, 2014 [In Chinese]. 
31. MEI X., YANG Y., TAM N.F., WANG Y., LI L. Roles of root porosity, radial oxygen loss, Fe plaque formation on nutrient removal and tolerance of wetland plants to domestic wastewater. Water Res. 50, 147, 2014.

32. MUELLER K., MASON K., GASTELUM STROZZI A., SIMPSON R., KOMATSU T., KAWAMOTO K., CLOTHIER B. Runoff and nutrient loss from a waterrepellent soil. Geoderma. 322, 28, 2018.

33. XIAO Y., TANG J., WANG M., ZHAI L., ZHANG X. Impacts of soil properties on phosphorus adsorption and fractions in purple soils. J Mt Sci-Engl. 14, 2420, 2017.

34. WANG T., ZHU B., KUANG F. Reducing interflow nitrogen loss from hillslope cropland in a purple soil hilly region in southwestern China. Nutr. Cycl. Agroecosys. 93, 285, 2012.

35. WU X., ZHANG L., YU X. Impacts of surface runoff and sediment on nitrogen and phosphorus loss in red soil region of southern China. Environ. Earth. Sci. 67, 1939, 2012.

36. ZHANG F., YANG M., LI B., LI Z., SHI W. Effects of slope gradient on hydro-erosional processes on an aeolian sand-covered loess slope under simulated rainfall. J. Hydrol. 553, 447, 2017.

37. DENG L., ZHANG L., FAN X., WU Y., SUN T., FEI $\mathrm{K}$. Characteristics of runoff and sediment yield under different rainfall intensities and slope gradients in erosive weathered granite area. Trans. Chin. Soc. Agric. Eng. (Trans. of the CSAE), 34, 143, 2018 [In Chinese].

38. FU Y., LI G., ZHENG T., LI B., ZHANG T. Splash detachment and transport of loess aggregate fragments by raindrop action. Catena. 150, 154, 2017.

39. MICHEL E., MAJDALANI S., DI-PIETRO L. A novel conceptual framework for long-term leaching of autochthonous soil particles during transient flow. Eur. J. Soil. Sci. 65, 336, 2014.

40. KINNELL P. Raindrop-impact-induced erosion processes and prediction: A review. Hydrol. Process, 19, 2815, 2005.

41. JANOS P., KOPECKA A., HEJDA S. Utilization of waste humate product (iron humate) for the phosphorus removal from waters. Desalination. 265, 88, 2011.

42. HEATHWAITE A.L., DILS R.M. Characterising phosphorus loss in surface and subsurface hydrological pathways. Sci. Total Environ. 251, 523, 2000.

43. DREWRY J.J., NEWHAM L.T.H., CROKE B.F.W. Suspended sediment, nitrogen and phosphorus concentrations and exports during storm-events to the Tuross estuary, Australia. J. Environ. Manage. 90, 879, 2009.

44. MATHERS N.J., NASH D.M. Effects of tillage practices on soil and water phosphorus and nitrogen fractions in a Chromosol at Rutherglen in Victoria, Australia. Austral. J. Soil Res. 47, 46, 2009.

45. HU J., GUO T., ZHUO M., CAI Q., XIE Z., LIAO Y., LI D. Erosion processes on red soil slope in south China under simulated rainfall system. Ecol. Environ. Sci. 22, 787, 2013 [In Chinese].

46. WANG C., ZHAO P., GAO M. Characteristics of nitrogen and phosphorus transportation through runoff in a typical ecological-hydrological unit of hilly area of purple soil. J. Hydraul. Eng. 44, 748, 2013.

47. WANG L., LIANG T., ZHANG Q. Laboratory experiments of phosphorus loss with surface runoff during simulated rainfall. Environ. Earth. Sci. 70, 2839, 2013.

48. ZIADAT F.M., TAIMEH A.Y. Effect of rainfall intensity, slope, land use and antecedent soil moisture on soil erosion in an arid environment. Land Degrad. Dev. 24, $582,2013$.

49. WANG J., HUANG J., WU P., ZHAO X. Application of neural network and grey relational analysis in ranking the factors affecting runoff and sediment yield under simulated rainfall. Soil Res. 54, 291, 2016.

50. CAMEIRA M.R., AHUJA L., FERNANDO R.M., PEREIRA L.S. Evaluating field measured soil hydraulic properties in water transport simulations using the RZWQM. J. Hydrol. 236, 78, 2000.

51. BAARTMAN J.E.M., JETTEN V.G., RITSEMA C.J., DE VENTE J. Exploring effects of rainfall intensity and duration on soil erosion at the catchment scale using openLISEM: Prado catchment, SE Spain. Hydrol. Process. 26, 1034, 2012.

52. ZHANG X., WANG Z. Interrill soil erosion processes on steep slopes. J. Hydrol. 548, 652, 2017.

53. BEGGY H.M., FEHMI J.S. Effect of surface roughness and mulch on semi-arid revegetation success, soil chemistry and soil movement. Catena. 143, 215, 2016.

54. LI G., ZHENG T., FU Y., LI B., ZHANG T. Soil detachment and transport under the combined action of rainfall and runoff energy on shallow overland flow. J. Mt. Sci. 14 (7), 1373, 2017. 